4 Fillenz, M., Proc. Roy. Soc., B, 174, 459 (1970).

${ }^{5}$ Laverty, R., and Taylor, K. M., Anal. Biochem., 22, 269 (1968).

"Viveros, O. H., Arqueros, L., and Kirshner, N., Life Sci., 7, 609 (1968).

Hvidt, A., Johansen, G., Linderström-Lang, K., and Vaslow, F., CR Trav. Lab. Carlsberg, Ser. Chim., 29, 129 (1954).

${ }^{8}$ Smith, A. D., De Potter, W. P., and De Schaepdryver, A. F., Arch. Intern. Pharmacodyn. 1\%9, 495 (1969).

'Hörtnagl, H., Hörtnagl, H., and Winkler, H., J. Physiol., 205, 103 (1969).

${ }^{10}$ Roth, R. H., Stjärne, L., Bloom, F. F., and Giarman, N. T., J. Pharmacol. Exp. Therap., 162, 203(1968).

\section{Effect of Steroids on the Cycling of Haemopoietic Stem Cells}

This report describes an effect (not previously reported) of single doses of steroids on the cell cycle of haemopoietic stem cells. This effect, ono of increasing the sensitivity of spleen colony forming units (CHU) to the lethal effects of ${ }^{3} \mathrm{H}$-thymidine, is seen well before the long-term effects of steroids on erythropoiesis ${ }^{1}$. Increased sensitivity of CFU to ${ }^{3} \mathrm{H}$-thymidine was also observed in steroid-treated polycythaemic mice. The latter finding suggests that the steroid offect is not mediated through erythropoietin.

Normal or polycy thaemic $\mathrm{C}_{3} \mathrm{H} \times \mathrm{AKR}$ female mico were used in these exporiments; they wero $9-11$ weeks old and weighed $25 \pm 2 \mathrm{~g}$. To suppress endogenous levels of erythropoietin ${ }^{2}$, mico were made polycythaomic by the method of hypertransfusion. The technique used in these experiments has been described previously ${ }^{3}$. T'estosterone propionate (TP), etiocholan-173-ol-3-one (ETIO), 19-nortestostcrone phenylpropionate (19-nor-TPP), and $\tilde{\delta} \alpha$-androstane (5 $\alpha$-AND) wero the steroids studied. A 1.8 per cent solution of medium viscosity carboxymothylcellulose (CMC) in physiological saline was used to suspend the compounds. Suspensions of steroids were $0.058 \mathrm{mmole} /$ inl. The agents were injected subcutaneously in a single dose of $2.9 \times 10^{-4} \mathrm{mmole} / \mathrm{g}$ of mouse; this was equivalent to $0.10 \mathrm{mg} / \mathrm{g}$ TP, $0.084 \mathrm{mg} / \mathrm{g}$ ETIO, $0.118 \mathrm{mg} / \mathrm{g}$ 19-norTPP, and $0.076 \mathrm{mg} / \mathrm{g} 5 \alpha$-AND.

TP was the only steroid studied in polycythaemic mice. 'To test whether TP causes an increase in endogenous erythropoietin levels, TP-treated polycythaemic mice were injected with $0.5 \mu \mathrm{Ci}{ }^{59} \mathrm{Fe} 54 \mathrm{~h}$ after steroid. Incorporation of ${ }^{58} \mathrm{Fe}$ into rod blood eclls was measured $72 \mathrm{~h}$ later ${ }^{3}$. This was compared with ${ }^{59} \mathrm{Fe}$ incorporation in control polyeythaemic mice.

CHU were estimated using the method of Till and $\mathrm{McCulloch}^{4}$. $6 \mathrm{~h}$ after treatment with either $\mathrm{CMC}$ or steroids, bone marrow was collected from the fomurs of two to four mice and pooled; the cells were suspended in $2.0 \mathrm{ml}$./femur of cold Fischer's medium. Sensitivity to ${ }^{3} \mathrm{H}$-thymidino ${ }^{5}$ was determined by incubating cell suspensions $\left(2.5-4.5 \times 10^{6}\right.$ cells $/ \mathrm{ml}$. $)$ in vitro at $37^{\circ} \mathrm{C}$ for $30 \mathrm{~min}$ with or without $200 \mu \mathrm{Ci} / \mathrm{ml}$. of high specific activity (13.4-22.8 $\mathrm{Ci} / \mathrm{mmole}){ }^{3} \mathrm{H}$-thymidine. After incubation the cell suspensions were adjusted to $2 \times 10^{5}$ cells $/ \mathrm{ml}$. with cold Fischer's medium. $5 \times 10^{4}$ cells were injected intravenously to mice (10-12 mice/group) previously given $850 \mathrm{rad}$ total-body $\mathrm{X}$-irradiation. Spleen colonies were counted 9-10 days after bone marrow transplantation. Sensitivity to ${ }^{3} \mathrm{H}$-thymidine was expressed as the per cent loss of CFU from cell suspen. sions incubated with ${ }^{3} \mathrm{H}$-thymidine:

${ }^{3} \mathrm{H}$-thymidine effect (per cent) $=100-$

$$
\left[\frac{\text { number of CFU with }{ }^{3} \mathrm{H} \text {-thymidine }}{\text { number of CFU without }{ }^{3} \mathrm{H} \text {-thymidine }} \times 100\right]
$$

The technique estimates, at best, the minimum per cent of CFU in DNA synthesis and therefore in cell cycle.

Table 1 gives the effects of ${ }^{3} \mathrm{H}$-thymidine on bone marrow from $\mathrm{CMC}$ and steroid treated mice. CFU from $\mathrm{CMC}$ and $5 \alpha$-AND treated mice were insensitive to ${ }^{3} \mathrm{H}$ -

Table 1. EFFECT OF ${ }^{3}$ H-THYMIDINE 6 H AFTER STEROID (NORYAL MICE)

\begin{tabular}{|c|c|c|}
\hline \multirow[b]{2}{*}{ Ireatment } & \multicolumn{2}{|c|}{$\mathrm{CFC} / 5 \times 10^{4}$ cells } \\
\hline & $\begin{array}{l}\text { Without } \\
{ }^{3} \mathrm{H} \text {-thymidine }\end{array}$ & $\begin{array}{l}\text { With } \\
{ }^{3} \mathrm{H} \text {-thymidine }\end{array}$ \\
\hline $\begin{array}{l}\text { CMC } \\
5 a-A N D\end{array}$ & $\begin{array}{l}9 \cdot 8 \pm 0.8 \\
9 \cdot 8+1.0\end{array}$ & $\begin{array}{r}10 \cdot 1 \pm 1 \cdot 0 \\
9 \cdot 7+0.5\end{array}$ \\
\hline TP & $9 \cdot 2+0 \cdot 9$ & $6 \cdot 3+0.5$ \\
\hline HTIO & $10 \cdot 3 \pm 0 \cdot 8$ & $7.0 \pm 0.7$ \\
\hline 19-nor-TPP & $13 \cdot 1 \pm 1 \cdot 2$ & $10 \cdot 3 \pm 1 \cdot 0$ \\
\hline
\end{tabular}

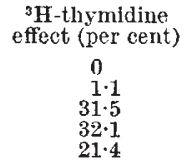

Table 2. EFHECT OF ${ }^{3} \mathrm{H}$-THYMLDINE $6 \mathrm{H}$ AFTER TP (POLYCYTHAEMIO MICF)

$\begin{array}{ccccc}\text { Treatment } & \begin{array}{c}\text { CFU } / 5 \times 10^{4} \text { cells } \\ \text { Without }\end{array} & \text { With } \\ { }^{3} \mathrm{H} \text {-thymidine } & { }^{3} \mathrm{H} \text {-thymidine } & \begin{array}{c}\text { H-thymidine } \\ \text { effect } \\ \text { (per cent) }\end{array} & \begin{array}{c}{ }^{59} \mathrm{Fe} \\ \text { incorpora- } \\ \text { tion* }\end{array} \\ \text { CMC } & 10 \cdot 6 \pm 0.5 & 11.0 \pm 0.8 & 0 & 0.20 \\ \text { TP } & 11.7 \pm 0.5 & 8.8 .50 .5 & 24.8 & 0.19\end{array}$

* Expressed as percentage injected dose of ${ }^{59} \mathrm{Fe}$.

thymidine. An increased sensitivity is shown for ( $Y F U$ from mice treated with either TP, ETIO, or 19-nor-TPP. Tablo 2 gives the results in polycythaemic animals. TP increased the sensitivity of CHU to ${ }^{3} \mathrm{H}$-thymidine without increasing the incorporation of ${ }^{59} \mathrm{Fe}$ into red blood cells.

These results demonstrate an effect of steroids, $6 \mathrm{~h}$ after injection, on the cycling of stem cells from mouse bone marrow. CFU of adult mouse bone marrow are insensitive to the killing action of ${ }^{3} \mathrm{H}$-thymidine ${ }^{5}$; for example, CMC group (Table 1). It is therefore assumed that normally CFU are not in cell cycle (that is, in a resting or $G_{0}$ stage), or have very long cell cycles. The results suggest that steroids may act to trigger haemo. poietic stern cells into cell cycle or to shorten their coll cycles. The mechanism by which steroids might trigger CFU into cycle must await future studies. The activity of TP in polycythaemic mice (Table 2) indicates, howover, that the steroid action doos not require the presence of erythropoietin. One may speculate that protein synthetic mechanisms at the level of transeription or translation are involved ${ }^{\text {B }}$.

The effectiveness of FTIO and 19-nor-'TPP' on the cyeling of $\mathrm{CFU}$ indicates that steroids with potent androgen activity, for example 'TP, are not required for increasing DNA synthosis in haemopoietic stem cells. In addition, the results with EIIO demonstrate that steroids with a $5 \beta$ configuration (A/B rings aro cis) may be active in the haemopoietic system. 'These findings are in agreement with those of others who have demonstrated the activity of steroids with the $5 \beta$ configuration on other components of the haemopoietic system ${ }^{\text {2-9 }}$.

Repopulation of the haemopoietic system, for example after damage by ionizing radiation or chemotherapeutic agents, depends, in part, upon the active proliferation of hacmopoietic stem colls; that is, CFU. As proliferation may not proceed immediately following damage, the trig. gering of CFU into cycle immediately after haemopoietic damage may lead to an carlicr recovery of the haemopoietic system. Preliminary studies indicate that TP given $1 \mathrm{~h}$ and $24 \mathrm{~h}$ after 150 rad total body $\mathrm{X}$-irradiation does lead to more rapid recovery of the CFU population ${ }^{10}$.

\section{J. W. Byron}

Haematology-Pharmacology Laboratory,

Paterson Laboratories,

Christie Hospital and Holt Radium Institute,

Manchester M20 9BX.

Received June 29, 1970.

${ }^{1}$ Ann. NY Acad. Sci., 149 (Part VI), 298 (1968). 'Jacobson, T. O., Goldwasser, E., and Gurney, C. W., Haemopoiesis (edit.
by Wolstenholme, G. E. W., and O'Connor, M.), 423 (Churehill, London, 1960).

3 Byron, J. W., and Lajtha, L. G., Brit. J. Haematol., 15, 47 (1968).

${ }^{4}$ Till, J. E., and M.Culloch, E. A., Radiat. Res., 14, 213 (1961).

Becker, A. J., McCulloch, E. A., Siminovitch, L., and Till, J. E., Blood, 26, Karlson, $\mathrm{Y} . \mathrm{P}$

Tappas, A Persp. Biol. Med., 6, 203 (1963).

, and Granick, S., J. Biol. Chem., 243, 346 (1968).

${ }^{8}$ Gorshein, D., and Gardner, F. H., Proc. US Nat. Acad. Sci., 65, 564 (1970). Gordon, A. S., Zanjani, E. D., Levere, R. D., and Kappas, A., Proc. US Nat. Acad. Sci., 65, 919 (1970).

${ }^{10}$ Byron, J. W., and Testa, Nydia, Thirteenth Intern. Cong. IIaematol. (1970). 